\title{
Composition Fractionation and Thermal Characterization of Poly(3-hydroxybutyrate-co-3-hydroxypropionate)
}

\author{
Amin CaO, Masafumi IchiKawa, Ken-ichi Kasuya, Naoko Yoshie, Naoki Asakawa, \\ Yoshio Inoue, ${ }^{\dagger}$ Yoshiharu DoI, ${ }^{*}$ and Hideki ABE* \\ Department of Biomolecular Engineering, Tokyo Institute of Technology, \\ 4259 Nagatsuta, Midori-ku, Yokohama 226, Japan \\ * The Institute of Physical and Chemical Research (RIKEN), 1 Hirosawa \\ 2-chome, Wako-shi, Saitama 351-01, Japan
}

(Received July 12, 1996)

\begin{abstract}
The compositional distribution has been investigated for poly(3-hydroxybutyrate-co-3-hydroxypropionate) $[\mathrm{P}(3 \mathrm{HB}-\mathrm{co}-3 \mathrm{HP})] \mathrm{s}$, which were microbially synthesized by Alcaligenes latus with 3-hydroxypropionic acid, sucrose or 3-hydroxybutyric acid as the sole carbon source. With a chloroform $/ n$-heptane mixed solvent, they were found to be fractionated into several fractions with different comonomer composition. It was concluded that the as-produced bacterial P(3HB-co-3HP) samples have a broad distribution of comonomer composition. Using the fractions with a narrower comonomer composition distribution, the composition dependence of thermal properties and isothermal spherulite growth behavior were investigated. One of as-produced unfractionated $\mathrm{P}(3 \mathrm{HB}-\mathrm{co}-3 \mathrm{HP})$ showed the DSC melting behavior reflecting that of only minor fractions with $3 \mathrm{HP}$ content differed remarkedly from average $3 \mathrm{HP}$ content of original unfractionated $\mathrm{P}(3 \mathrm{HB}-\mathrm{co}-3 \mathrm{HP})$. It was concluded that each of the fractions affects thermal properties of the original $\mathrm{P}(3 \mathrm{HB}-c o-3 \mathrm{HP})$.

KEY WORDS Poly(3-hydroxybutyrate-co-3-hydroxypropionate)/Fractionation / Comonomer Composition Distribution / Thermal Behavior / Spherulite Growth /
\end{abstract}

Microbially synthesized poly(3-hydroxybutyrate) $[\mathrm{PHB}]$ is naturally occurring thermal plastics, which attract the industrialists and researchers for it's special properties of environmental biodegradability and biocompatibility. ${ }^{1-5}$ It appears as an intercellular storage material of carbon and energy by a variety of bacteria. Wide range of properties have been intensively studied for this kind of polymer, such as the mechanism of biosynthesis, microstructure, thermal behaviors, mechanical properties, enzymatical degradation process, and so forth. ${ }^{6-16}$

However, there exist several deficiencies of PHB as an engineering material for it's inherent properties of brittleness and thermal unstabililty above melting point. ${ }^{6,13}$ To modify the properties of PHB, a series of copolymers, such as poly(3-hydroxybutyrate-co-3-hydroxyvalerate) $[\mathrm{P}(3 \mathrm{HB}-c o-3 \mathrm{HV})]$, poly(3-hydroxybutyrate-co-4-hydroxybutyrate) $[\mathrm{P}(3 \mathrm{HB}-c o-4 \mathrm{HB})]$, and poly(3-hydroxybutyrate-co-3-hydroxypropionate) $[\mathrm{P}(3 \mathrm{HB}-$ co-3HP)] have been produced by a variety of bacteria with respect to specific carbon source. ${ }^{1,6,17-21}$

In the previous works, ${ }^{22-24}$ microbial synthesized $\mathrm{P}(3 \mathrm{HB}-\mathrm{co}-3 \mathrm{HV})$ samples have been successfully fractionated through a process of solvent/non-solvent precipitation, such as a cholorform $/ n$-heptane mixed solvent, series of fractions were obtained with different $3 \mathrm{HV}$ repeating unit composition. On observation, it was noted that the natural copolyester $\mathrm{P}(3 \mathrm{HB}-c o-3 \mathrm{HP}) \mathrm{s}$ were mixtures with a broad comonomer compositional distribution. The dependences of physical properties on 3HV repeating unit composition, such as melting temperature, crystallization behavior, etc., have been studied.

Recently, the compositonal dependence of some properties have also been investigated for as-produced natural $\mathrm{P}(3 \mathrm{HB}-c o-3 \mathrm{HP}) \mathrm{s} .{ }^{25}$ According to the results of

\footnotetext{
† To whom correspondence should be addressed.
}

$\mathrm{P}(3 \mathrm{HB}-\mathrm{co}-3 \mathrm{HV})$, it is reasonable to suppose that $\mathrm{P}(3 \mathrm{HB}-c o-3 \mathrm{HP}) \mathrm{s}$ extracted from bacterial syntheses are also a mixture of several copolyesters with different 3HP monomer composition, and each component affects the physical properties of the "original" $\mathrm{P}(3 \mathrm{HB}-c o-3 \mathrm{HP}) \mathrm{s}$.

In the present work, we attempt to fractionate the bacterially synthesized $\mathrm{P}(3 \mathrm{HB}-c o-3 \mathrm{HP})$ s by the difference of comonomer composition to reveal the effect of each component on the physical properties of the original copolyester, which were accumulated by Alcaligenes latus fed on mixed carbon substrates: 3-hydroxypropionic acid (3HPA), sucrose or 3-hydroxybutyric acid (3HBA). With a chloroform $/ n$-heptane mixed solvent, several P(3HB$c o-3 \mathrm{HP})$ fractions with a narrower comonomer compositional distribution were obtained from the original $\mathrm{P}(3 \mathrm{HB}-\mathrm{co}-3 \mathrm{HP}) \mathrm{s}$ with a range of $3 \mathrm{HP}$ repeating unit composition from 26.4 to $62.0 \mathrm{~mol} \%$. The melting temperature, enthalpies of fusion $(\Delta H)$, isothermal spherulite growth and crystallization behaviors were studied, together with their original copolymers simultaneously.

\section{EXPERIMENTAL}

\section{Biosynthesis of $P(3 H B-c o-3 H P)$}

In this study, biosynthesis of copolyester $\mathrm{P}(3 \mathrm{HB}-c o-$ 3HP) was carried out by one stage fermentation with Alcaligenes latus. ${ }^{20}$ The bacteria were grown at $30^{\circ} \mathrm{C}$ under aerobic conditions on a shaker in $500 \mathrm{ml}$ Sakaguchi flasks with $200 \mathrm{ml}$ cultivation media, which contained a mixed carbon substrate as following: 3HPA, sucrose or 3HBA with respect to different cultivation situation. The medium simultaneously contained inorganic compounds: $8.6 \mathrm{~g}$ of $\mathrm{Na}_{2} \mathrm{HPO}_{4} \cdot 12 \mathrm{H}_{2} \mathrm{O}, 1.5 \mathrm{~g}$ of $\mathrm{KH}_{2} \mathrm{PO}_{4}, 1.0 \mathrm{~g}$ of $\left(\mathrm{NH}_{4}\right)_{2} \mathrm{SO}_{4}, 0.2 \mathrm{~g}$ of $\mathrm{MgSO}_{4} \cdot 7 \mathrm{H}_{2} \mathrm{O}, 0.06 \mathrm{~g}$ of ammonium iron(III) citrate, and $0.01 \mathrm{~g}$ of $\mathrm{CaCl}_{2} \cdot 2 \mathrm{H}_{2} \mathrm{O}$ per liter of distilled water. $1 \mathrm{ml}$ of microelement solution was added to the above mentioned medium, including: $0.3 \mathrm{~g}$ of 
$\mathrm{H}_{3} \mathrm{BO}_{3}, 0.2 \mathrm{~g}$ of $\mathrm{CoCl}_{2} \cdot 6 \mathrm{H}_{2} \mathrm{O}, 0.1 \mathrm{~g}$ of $\mathrm{ZnSO}_{4} \cdot 7 \mathrm{H}_{2} \mathrm{O}$, $0.03 \mathrm{~g}$ of $\mathrm{MnCl}_{2} \cdot 2 \mathrm{H}_{2} \mathrm{O}, 0.03 \mathrm{~g}$ of $\mathrm{NaMoO}_{4} \cdot 2 \mathrm{H}_{2} \mathrm{O}, 0.02 \mathrm{~g}$ of $\mathrm{NiCl}_{2} \cdot 6 \mathrm{H}_{2} \mathrm{O}, 0.01 \mathrm{~g}$ of $\mathrm{CuSO}_{4} \cdot 5 \mathrm{H}_{2} \mathrm{O}$ per liter of $1.0 \mathrm{~N}$ $\mathrm{HCl}$ and $\mathrm{pH}$ value was adjusted to 7.0 by $\mathrm{NaOH}$ solution before starting fermentation. Bacteria were incubated for 6 days and harvested by centrifugation, washed with distilled water, and followed by lyophilization. Copolyesters were extracted from the lyophilized cells with hot chloroform using a Soxhlet apparatus, and purified by repreciptation with $n$-hexane and methanol. Poly( $\beta$-propiolactone) $[\mathrm{PPL}]\left(M_{n}, 2.7 \times 10^{5} ; M_{w} / M_{n}, 2.1\right)$, which was chemically synthesized through ring-opening polymerization, was kindly supplied by Tokuyama Corp. (Tsukuba, Japan).

\section{Fractionation of As-Produced $\mathrm{P}(3 \mathrm{HB}-\mathrm{co}-3 \mathrm{HP})$}

Microbial P(3HB-co-3HP) denoted "original" samples, were fractionated with a chloroform $/ n$-heptane mixed solvent at ambient temperature. The fractionating procedure was described as following: $1.0 \mathrm{~g}$ of original sample was dissolved in chloroform, and $n$-heptane was added to this solution by micro-unit under a gentle agitation. Some amount of copolyester fraction with high 3HP composition deposited from the mixed solvent. Thus this solution was kept at room temperature for $24 \mathrm{~h}$, and the firstly precipitated sample was obtained by centrifugation. This procedure was repeated until adding any amount of $n$-heptane could not cause further sedimentation of copolyester. Finally, the residual copolyester in the uppernant solution was recovered by vaporization of solvents. All of the fractions were dried in the vacuum oven for about $48 \mathrm{~h}$ before measurements.

\section{${ }^{1} H$ NMR Measurement}

To determine the $3 \mathrm{HP}$ unit composition of as-produced as well as fractionated samples of $\mathrm{P}(3 \mathrm{HB}-\mathrm{co}-3 \mathrm{HP}),{ }^{1} \mathrm{H}$ NMR spectra were recorded on a JEOL GSX-270 spectrometer at $30^{\circ} \mathrm{C}$ in $\mathrm{CDCl}_{3}$ solutions with a $4.5 \mu$ s pusle width $\left(45^{\circ}\right.$ pulse angle), $5 \mathrm{~s}$ pulse repetition time, $2500 \mathrm{~Hz}$ spectral width, $32 \mathrm{~K}$ data points and 32 FID accumulations.

\section{Characterization by Gel Permeation Chromatography}

Molecular weights of as-produced as well as fractionated samples were characterized by a Tosoh HLC8020 GPC system with a Tosoh SC-8010 controller and a refractive detector with TSK GEL G2000Hxl and GMHxl columns, chloroform was used as the eluant at a flowing rate of $1.0 \mathrm{ml} \mathrm{min}^{-1}$, the concentration of sample was about $1.0 \mathrm{mg} \mathrm{ml}^{-1}$, and polystyrene with a narrow molecular distribution was used as a standard to calibrate the curve. Number average mo- lecular weight $\left(M_{n}\right)$, weight average molecular weight $\left(M_{w}\right)$ and ploydispersity $\left(M_{w} / M_{n}\right)$ were calculated from the GPC data through a SC-8010 data processor.

\section{Measurement of DSC}

Calorimetric measurements of the copolyesters (5$7 \mathrm{mg}$ ), which were encapsulated in a aluminum pan, were carried out on a Seiko DSC-20 assemblied with a SSC-580 thermal controller. Before measurement, the samples cast from chloroform solution were kept for more than 3 weeks at room temperature, likewise samples cooled from the melt were annealed in an oven for one month in order to approach their equilibrium state under a given temperature. Thermograms were recorded by heating samples from $0^{\circ} \mathrm{C}$ to $200^{\circ} \mathrm{C}$, and melting temperature was taken as the summit of melting peak, moreover, enthalpies of fusion $(\Delta H)$ were calculated from the area of endotherm curve (first heating run).

\section{Isothermal Spherulite Growth Behavior}

Isothermal spherulite growth behavior was investigated on a polarized microscope of Olympus BX90 equipped with a Mettler FP82HT hot stage under different supercooling condition. Films of the samples were firstly heated to a temperature of $210^{\circ} \mathrm{C}$, then cooled to a given crystallization temperature $\left(T_{\mathrm{c}}\right)$ with a thermal programming rate of $20^{\circ} \mathrm{C} \mathrm{min}^{-1}$. The relation between spherulite radius and growing time $(t)$ was proved to be linear, and rates of isothermal spherulites growth $(G)$ were taken as the slope of the radius against time plot.

\section{RESULTS AND DISCUSSION}

In this work, based on a single stage cultivation, ${ }^{20}$ microbial $\mathrm{P}(3 \mathrm{HB}-\mathrm{co}-3 \mathrm{HP})$ s were synthesized by fermentation of Alcaligenes latus with a series of mixed carbon sources. The results of biosyntheses were described in Table I, in which the composition of comonomer was determined from the relative integrated intensities of the proton resonances of the $3 \mathrm{HB}$ and $3 \mathrm{HP}$ repeating units in the ${ }^{1} \mathrm{H}$ NMR spectrum. It was noted that increasing 3HPA composition of the mixed substrate resulted in an increase of the $3 \mathrm{HP}$ unit in $\mathrm{P}(3 \mathrm{HB}-\mathrm{co}-3 \mathrm{HP})$ copolyester with a range from 26.4 to $62.0 \mathrm{~mol} \%$, while the dry weight of cell and polyester content were decreased significantly. Shimamura et al. ${ }^{20}$ reported that Alcaligenes latus could not accumulate copolyester in a medium using a substrate of 3HPA as the unique carbon source, due to the fact that 3HPA could not be used for cell growth.

The biosynthesized $\mathrm{P}(3 \mathrm{HB}-\mathrm{co}-3 \mathrm{HP}) \mathrm{s}$, which were de-

Table I. Production of $\mathrm{P}(3 \mathrm{HB}-c o-3 \mathrm{HP})$ from $R-(-)-3$-hydroxybutyric acid (3HBA) and 3-hydroxypropionic acid (3HPA) by Alcaligenes latus at $30^{\circ} \mathrm{C}$

\begin{tabular}{|c|c|c|c|c|c|c|c|c|}
\hline \multirow{2}{*}{$\begin{array}{c}\text { Sample } \\
\text { lot. }\end{array}$} & \multicolumn{3}{|c|}{ Carbon source $/ \mathrm{gl}^{-1}$} & \multirow{2}{*}{ Days } & \multirow{2}{*}{$\begin{array}{c}\begin{array}{c}\text { Cell dry } \\
\mathrm{wt}\end{array} \\
\mathrm{g} \mathrm{l}^{-}\end{array}$} & \multirow{2}{*}{$\begin{array}{c}\begin{array}{c}\text { Polyester } \\
\text { wt }\end{array} \\
\mathrm{g} \mathrm{l}^{-1}\end{array}$} & \multirow{2}{*}{$\begin{array}{c}\begin{array}{c}\text { Polyester } \\
\text { content }\end{array} \\
\mathrm{wt} \%\end{array}$} & \multirow{2}{*}{$\begin{array}{c}\begin{array}{c}\text { Polyester } \\
\text { composition }\end{array} \\
3 \mathrm{HP} \text { mol\% }\end{array}$} \\
\hline & Sucrose & $3 \mathrm{HBA}$ & $3 \mathrm{HPA}$ & & & & & \\
\hline A & 0 & 5.0 & 1.0 & 6 & 2.4 & 1.2 & 53 & 30.6 \\
\hline B & 5.0 & 0 & 2.0 & 6 & 2.1 & 0.7 & 36 & 26.4 \\
\hline $\mathrm{C}$ & 0 & 2.0 & 4.0 & 6 & 1.2 & 0.3 & 28 & 62.0 \\
\hline
\end{tabular}


Table II. Fractionated results for $\mathrm{P}(3 \mathrm{HB}-\mathrm{co}-30.6 \mathrm{~mol} \% 3 \mathrm{HP})$ sample A

\begin{tabular}{|c|c|c|c|c|c|}
\hline \multirow{2}{*}{$\begin{array}{c}\text { Fraction } \\
\text { no. }\end{array}$} & $\begin{array}{l}\text { Concn. of } \\
n \text {-heptane }\end{array}$ & \multirow[t]{2}{*}{$\mathrm{wt} \%$} & $\begin{array}{c}\text { 3HP } \\
\text { content }^{b}\end{array}$ & \multirow[t]{2}{*}{$10^{-5} M_{n}$} & \multirow[t]{2}{*}{$M_{n} / M_{w}$} \\
\hline & $\%$ & & $\mathrm{~mol} \%$ & & \\
\hline $0^{\mathbf{a}}$ & - & 100 & 30.6 & 3.2 & 2.3 \\
\hline 1 & 40.5 & 8.3 & 60.5 & 2.7 & 2.8 \\
\hline 2 & 43.8 & 10.2 & 47.4 & 2.8 & 2.5 \\
\hline 3 & 49.3 & 8.9 & 39.1 & 2.1 & 2.6 \\
\hline 4 & 49.4 & 8.2 & 35.6 & 2.8 & 2.8 \\
\hline 5 & 53.2 & 6.4 & 28.4 & 2.3 & 2.0 \\
\hline 6 & 55.1 & 15.1 & 23.6 & 3.5 & 2.1 \\
\hline 7 & 55.8 & 13.4 & 20.0 & 3.1 & 1.8 \\
\hline 8 & 58.9 & 8.8 & 18.1 & 3.0 & 1.8 \\
\hline 9 & 61.2 & 8.3 & 15.8 & 2.5 & 1.8 \\
\hline 10 & 64.5 & 7.0 & 12.8 & 1.0 & 1.9 \\
\hline 11 & 68.4 & 5.4 & 8.5 & 1.4 & 1.9 \\
\hline
\end{tabular}

${ }^{a}$ original sample A. ${ }^{\mathrm{b}}$ average $3 \mathrm{HP}$ content calculated from $3 \mathrm{HP}$ contents of fractions deviated slightly from the $3 \mathrm{HP}$ content of original sample owing to the inevitable loss during the repeated fractionational precipitation processes.

Table III. Fractionated results for $\mathrm{P}(3 \mathrm{HB}-\mathrm{co}-26.4 \mathrm{~mol} \% 3 \mathrm{HP})$ sample B

\begin{tabular}{|c|c|c|c|c|c|}
\hline \multirow{2}{*}{$\begin{array}{c}\text { Fraction } \\
\text { no. }\end{array}$} & $\begin{array}{l}\text { Concn. of } \\
n \text {-heptane }\end{array}$ & \multirow[t]{2}{*}{$w t \%$} & $\begin{array}{c}3 \mathrm{HP} \\
\text { content }^{\mathrm{b}}\end{array}$ & \multirow[t]{2}{*}{$10^{-5} M_{n}$} & \multirow[t]{2}{*}{$M_{n} / M_{w}$} \\
\hline & $\%$ & & $\mathrm{~mol} \%$ & & \\
\hline $0^{\mathrm{a}}$ & - & 100 & 26.4 & 3.2 & 2.1 \\
\hline 1 & 44.1 & 17.6 & 54.2 & 3.8 & 1.6 \\
\hline 2 & 52.9 & 13.4 & 35.7 & 4.2 & 1.5 \\
\hline 3 & 56.6 & 21.1 & 22.0 & 2.6 & 2.0 \\
\hline 4 & 64.2 & 48.0 & 14.8 & 3.2 & 1.5 \\
\hline
\end{tabular}

${ }^{a, b}$ See a footnotes of Table II.

Table IV. Fractionated results for $\mathrm{P}(3 \mathrm{HB}-\mathrm{co}-62.0 \mathrm{~mol} \% 3 \mathrm{HP})$ sample $\mathrm{C}$

\begin{tabular}{|c|c|c|c|c|c|}
\hline \multirow{2}{*}{$\begin{array}{c}\text { Fraction } \\
\text { no. }\end{array}$} & $\begin{array}{l}\text { Concn. of } \\
n \text {-heptane }\end{array}$ & \multirow[t]{2}{*}{$\mathrm{wt} \%$} & $\begin{array}{c}\text { 3HP } \\
\text { content }^{b}\end{array}$ & \multirow[t]{2}{*}{$10^{-5} M_{n}$} & \multirow[t]{2}{*}{$M_{n} / M_{w}$} \\
\hline & $\%$ & & $\mathrm{~mol} \%$ & & \\
\hline $0^{\mathrm{a}}$ & - & 100 & 62.0 & 1.3 & 2.1 \\
\hline 1 & 35.3 & 11.2 & 85.3 & 1.4 & 2.0 \\
\hline 2 & 36.2 & 12.8 & 80.6 & 1.2 & 1.9 \\
\hline 3 & 39.8 & 20.4 & 69.4 & 1.2 & 2.1 \\
\hline 4 & 42.1 & 17.4 & 63.4 & 1.3 & 3.2 \\
\hline 5 & 45.2 & 19.6 & 50.6 & 1.3 & 2.3 \\
\hline 6 & 48.0 & 21.3 & 41.3 & 1.1 & 2.8 \\
\hline
\end{tabular}

${ }^{\mathrm{a}, \mathrm{b}}$ See the footnotes of Table II.

noted "original" samples in order to be distinguished from their fractions, were fractionated with a chloroform $/ n$-heptane mixed solvent. The characteristics of the obtained fractions were measured and described in Tables II, III, and IV, indicating clearly that the fractionation was proceeded mainly by difference in 3HP content. The data shown in these Tables reveal that the $3 \mathrm{HP}$ content of the fractionated $\mathrm{P}(3 \mathrm{HB}-c o-3 \mathrm{HP})$ gradually decreases with increasing concentration of $n$ heptane in mixed solvent. It is intriguing to note that,

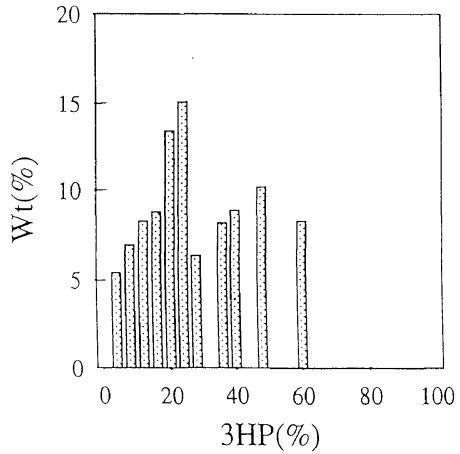

Figure 1. Weight percent of fractions $v s .3 \mathrm{HPmol} \%$ for $\mathrm{P}(3 \mathrm{HB}-c o-$ 3HP) sample A.

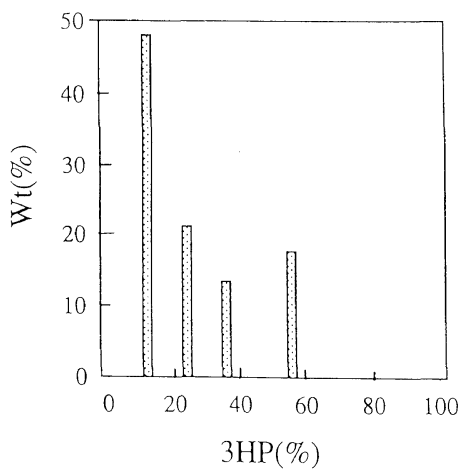

Figure 2. Weight percent of fractions $v$ s. $3 \mathrm{HP}$ mol $\%$ for $\mathrm{P}(3 \mathrm{HB}-\mathrm{co}-$ 3HP) sample B.

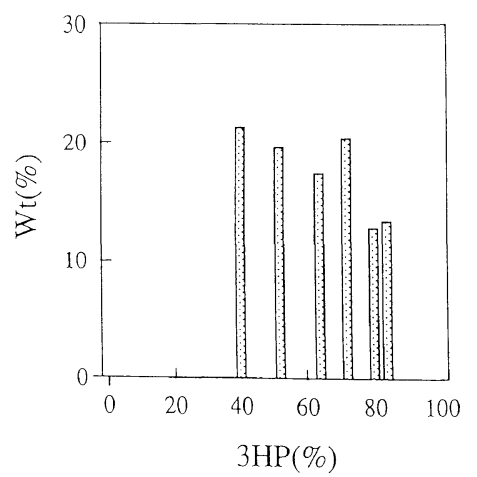

Figure 3. Weight percent of fractions $v$ s. $3 \mathrm{HP} \mathrm{mol} \%$ for $\mathrm{P}(3 \mathrm{HB}-c o-$ 3HP) sample C.

in the case of fractionational precipitation of $\mathrm{P}(3 \mathrm{HB}-\mathrm{co}-$ $3 \mathrm{HV})$ samples by using chloroform $/ n$-heptane mixed solvent, the $3 \mathrm{HV}$ content of precipitated fractions increases as the concentration of $n$-heptane in solution increases. ${ }^{23}$ Thus, the solubility of the $\mathrm{P}(3 \mathrm{HB}), \mathrm{P}(3 \mathrm{HB}-$ co-3HP), and $\mathrm{P}(3 \mathrm{HB}-c o-3 \mathrm{HV})$ samples depends on the type of side-chain and composition of constituent monomer units. Higher the content of the monomer units with longer side chain is, higher is the solubility of copolyesters in the mixed solvent with higher $n$-heptane content. In the case of sample A, the fraction with the lowest $3 \mathrm{HP}$ content has the lowest average molecular weight. But the dependence of molecular weight on the solvent composition is not clear.

Furthermore, in order to show more clearly the above mentioned results, Figures 1, 2, and 3 were simultaneously depicted. The 3HP content of the fractions obtained from sample $\mathrm{A}, \mathrm{P}(3 \mathrm{HB}-c o-30.6 \mathrm{ml} \% 3 \mathrm{HP})$, is 
ranged from $8.5 \mathrm{~mol} \%$ to $60.5 \mathrm{~mol} \%$. Here, for example, $\mathrm{P}(3 \mathrm{HB}-c o-30.6 \mathrm{~mol} \% 3 \mathrm{HP})$ indicates the unfractionated, original $\mathrm{P}(3 \mathrm{HB}-\mathrm{co}-3 \mathrm{HP})$ sample with $3 \mathrm{HP}$ content of $30.6 \mathrm{~mol} \%$. The compositional distribution of sample $A$ is quite broad and the fractions with $3 \mathrm{HP}$ content close to that of original sample are not the main constituents.

Though the apparent $3 \mathrm{HP}$ contet of samples A and B is quite similar to each other, the details of compositional distribution are quite diffferent. That is, sample $B$, $\mathrm{P}(3 \mathrm{HB}-\mathrm{co}-26.4 \mathrm{~mol} \% 3 \mathrm{HP})$, was fractionated into four fractions with well-separated $3 \mathrm{HP}$ content. The fraction with $3 \mathrm{HP}$ content of $14.8 \mathrm{~mol} \%$, which is significantly lower than that of the original sample, appears to be the main constituent, and the distribution is highly asymmetric. Sample C, P(3HB-co- $62.0 \mathrm{~mol} \%)$, was also composed of fractions with broad comonomer compositional distribution ranged from 41.3 to $85.3 \mathrm{~mol} \% 3 \mathrm{HP}$. These results implied that the natural $\mathrm{P}(3 \mathrm{HB}-c o-3 \mathrm{HP}) \mathrm{s}$ were not uniform copolyesters, but mixtures of $\mathrm{P}(3 \mathrm{HB}-$ co-3HP) copolymers with a wide range of comonomer compositional distribution.

To investigate the effects of composition distribution on the physical properties of $\mathrm{P}(3 \mathrm{HB}-\mathrm{co}-3 \mathrm{HP})$, DSC thermograms were measured. Results of the fractions together with their original samples $\mathrm{A}$ and $\mathrm{C}$, were illustrated in Figures 4 and 5. These samples were cast from chloroform solution and annealed for more than 3 weeks at ambient temperature before starting DSC measurements. The heating rate was designated $20^{\circ} \mathrm{C}$ $\min ^{-1}$ in the first heating scan. The DSC results showed that peaks of melting point had a tendency to shift for lower temperature with an increase of $3 \mathrm{HP}$ content, and the multiple peaks of fusion appeared in the case of $\mathrm{P}(3 \mathrm{HB}-\mathrm{co}-3 \mathrm{HP})$ samples with lower or higher $3 \mathrm{HP}$ unit constituent, as samples liked $\mathrm{P}(3 \mathrm{HB}-\mathrm{co}-$ $8.5 \mathrm{~mol} \% 3 \mathrm{HP}), \mathrm{P}(3 \mathrm{HB}-c o-12.8 \mathrm{~mol} \% 3 \mathrm{HP}), \mathrm{P}(3 \mathrm{HB}-$ co- $15.8 \mathrm{~mol} \% 3 \mathrm{HP})$ depicted in Figure 4, and P(3HB-co$85.3 \mathrm{~mol} \%$ 3HP) which was shown in Figure 5, with underlined $3 \mathrm{HP}$ composition representing fractions for a clear distinction between original and fractionated samples. In Figure 4, it is clear that the overall shape of DSC thermal diagram for original sample $\mathrm{A}$, that is, $\mathrm{P}(3 \mathrm{HB}-\mathrm{co}-30.6 \mathrm{~mol} \% 3 \mathrm{HP})$ is quite resembled to that of the fraction with $3 \mathrm{HP}$ constituent of $12.8 \mathrm{~mol} \%, \mathrm{P}(3 \mathrm{HB}-$ co- $12.8 \mathrm{~mol} \% 3 \mathrm{HP}$ ), but not similar to those with $3 \mathrm{HP}$ content of $28.4 \mathrm{~mol} \%$ and $35.6 \mathrm{~mol} \%, \mathrm{P}(3 \mathrm{HB}-\mathrm{co}-$ $28.4 \mathrm{~mol} \% 3 \mathrm{HP})$ and $\mathrm{P}(3 \mathrm{HB}-\mathrm{co}-35.6 \mathrm{~mol} \% 3 \mathrm{HP})$, although the $3 \mathrm{HP}$ content of these latter two fractions are close to that of the original sample. The weight fraction of $\mathrm{P}(3 \mathrm{HB}-\mathrm{co}-12.8 \mathrm{~mol} \% 3 \mathrm{HP})$ is only $7.0 \mathrm{wt} \%$ of the original sample. However, the profile of DSC thermogram for the unfractionated sample $\mathrm{P}(3 \mathrm{HB}-\mathrm{co}$ $30.6 \mathrm{~mol} \% 3 \mathrm{HP})$ mainly reflects that of the minor fraction $\mathrm{P}(3 \mathrm{HB}-\mathrm{co}-12.8 \mathrm{~mol} \% 3 \mathrm{HP})$. Therefore, the unfractionated $\mathrm{P}(3 \overline{\mathrm{HB}}-\mathrm{co}-30.6 \mathrm{~mol} \% 3 \mathrm{HP})$ sample does not show the DSC melting behavior expected for fractionated $\mathrm{P}(3 \mathrm{HB}-$ co-3HP) sample with the $3 \mathrm{HP}$ content corresponding to the average $3 \mathrm{HP}$ composition of unfractionated sample.

In order to discriminate which of the multipeaks was arisen from the melting of recrystallized phase. DSC measurements under different heating rate were carried

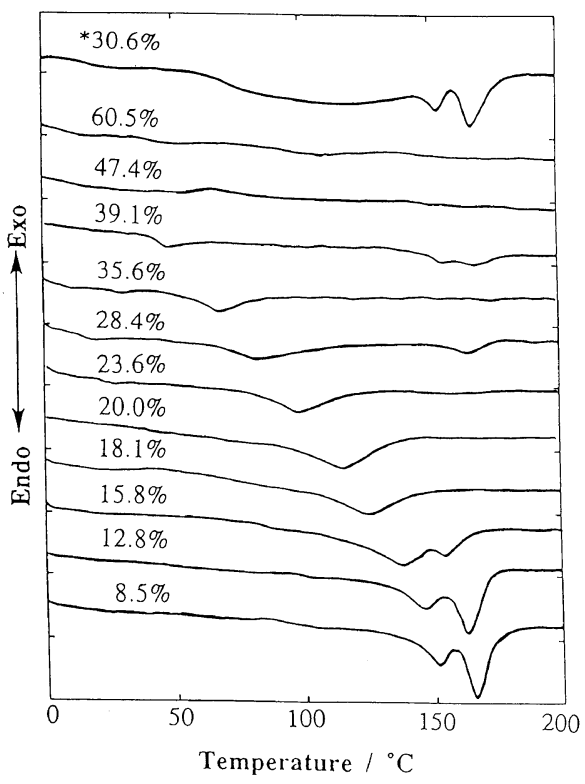

Figure 4. DSC diagrams of unfractionated original sample A (asterisked) and its series of fractions cast from solution (first heating scan).

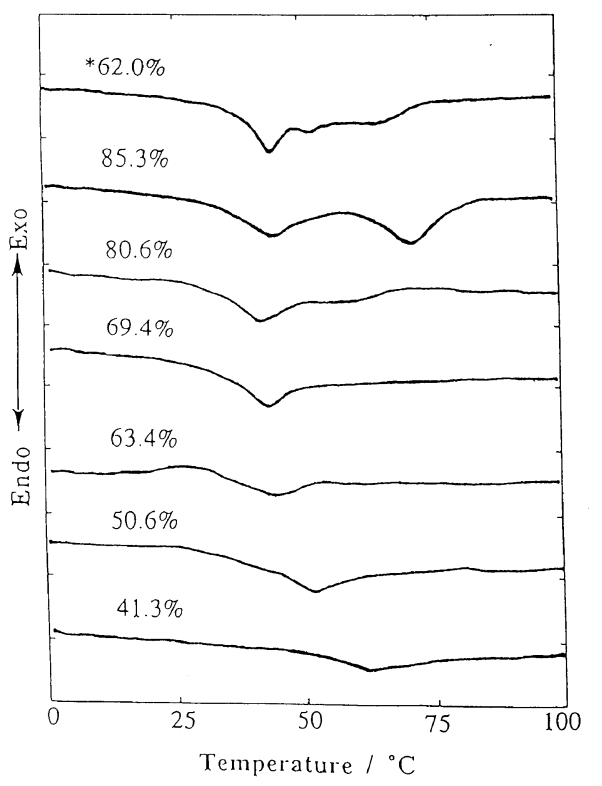

Figure 5. DSC diagrams of unfractionated original sample C (asterisked) and its series of fractions cast from solution (first heating scan).

out, which were based on the fractionated samples of $\mathrm{P}(3 \mathrm{HB}-\mathrm{co}-8.5 \mathrm{~mol} \% 3 \mathrm{HP})$ and $\mathrm{P}(3 \mathrm{HB}-\mathrm{co}-15.8 \mathrm{~mol} \%$ $3 \mathrm{HP})$. The results shown in Figure 6 are clearly indicating that the position and intensity of the peak at higher temperature varied with the heating rate, which was relative to the peak at lower temperature. Evenmore, the peak at high temperature of $\mathrm{P}(3 \mathrm{HB}-\mathrm{co}-15.8 \mathrm{~mol} \% 3 \mathrm{HP})$ disappeared at a heating rate of $40^{\circ} \mathrm{C} \mathrm{min}^{-1}$. These results mean that the peak at lower temperature was a real melting point $\left(T_{\mathrm{m}}\right)$, while the higher was the melting peak, due to recrystallized phase in the case the lattice of copolyester had enough time to be re-arranged at a given heating rate.

There also exist several unexpected small melting peaks at the higher temperature around $160^{\circ} \mathrm{C}$ in the DSC 


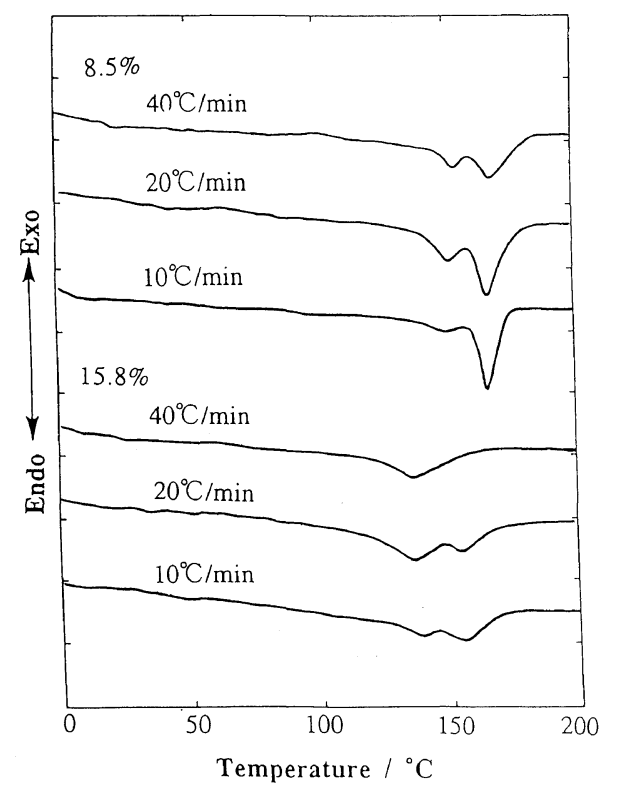

Figure 6. DSC diagrams under different heating rate of samples of $\mathrm{P}(3 \mathrm{HB}-\mathrm{co}-8.5 \mathrm{~mol} \% 3 \mathrm{HP})$ and $\mathrm{P}(3 \mathrm{HB}-c o-15.8 \mathrm{~mol} \% 3 \mathrm{HP})($ first heating scan).

diagrams of fractionated samples, such as $\mathrm{P}\left(3 \mathrm{HB}-\mathrm{co}^{-}\right.$ $39.1 \mathrm{~mol} \% 3 \mathrm{HP}$ ) and $\mathrm{P}(3 \mathrm{HB}-\mathrm{co}-28.4 \mathrm{~mol} \% 3 \mathrm{HP})$ shown in Figure 4, which should result from the deficiencies of fractionation procedure. Kumagai et al. ${ }^{18}$ reported that blends of natural PHB and chemically synthesized PPL are immiscible. Therefore, the peaks around $160^{\circ} \mathrm{C}$ suggest to be caused by the influence of minor fractions with lower 3HP repeating unit content, which were phase separated from the main fractions.

From the DSC diagram, melting temperature was derived as the temperature at the top of melting peak (first heating run). The enthalpies of fusion $(\Delta H)$ were calculated from the area of endothermic curves. Figures 7 and 8 showed that the melting temperature varied with $3 \mathrm{HP}$ content of $\mathrm{P}(3 \mathrm{HB}-c o-3 \mathrm{HP})$ polymer, and at $3 \mathrm{HP}$ content of about $60 \mathrm{~mol} \%$ a minimum melting temperature existed, which was completely consistent with the relation between $\Delta H$ and $3 \mathrm{HP}$ content. It also implied that minimum crystallinity exsited for the disturbance to the lattice caused by the second repeating unit. In the previous study, it was reported that the $3 \mathrm{HB}$ and 3HP units of $\mathrm{P}(3 \mathrm{HB}-\mathrm{co}-3 \mathrm{HP})$ could not cocrystallize, ${ }^{26}$ and only one set of parameters of PHB lattice was detected for $3 \mathrm{HP}$ content up to $60 \mathrm{~mol} \%$. $^{20}$ Further study using samples with higher 3HP composition was needed, with respect to this aspect.

The DSC thermal behaviors of the samples prepared by cooling the melt were compared to those from solution cast. The results were shown in Figures 9, 10, and 11. In Figure 9, the positions and intensities of DSC peaks are also varied with the $3 \mathrm{HP}$ content of fractionated samples, multiple melting peaks were observed in samples with lower $3 \mathrm{HP}$ content, which indicated about the same behavior with the results shown in Figure 4, while the melting points $\left(T_{\mathrm{m}}\right)$ are a little more increased, which is due to the increase of lamellar size caused by isothermal crystallization in a $60^{\circ} \mathrm{C}$ oven for one month, but the inceases of melting point and enthapies of fusion are not so remarked. It implies that $\mathrm{P}(3 \mathrm{HB}-\mathrm{co}-3 \mathrm{HP}) \mathrm{s}$ have 1100

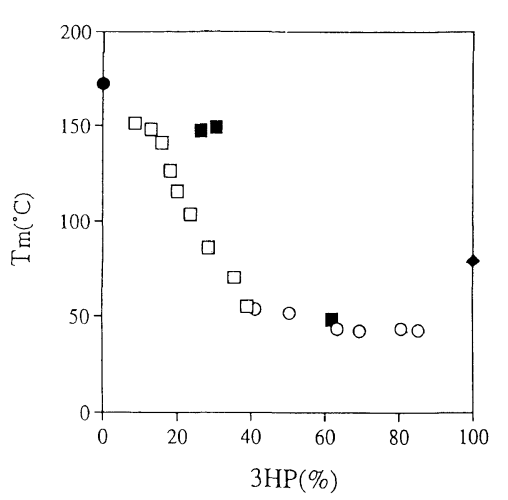

Figure 7. Melting temperature $\left(T_{\mathrm{m}}\right)$ vs. $3 \mathrm{HP} \mathrm{mol} \%$ for the fractionated $\mathrm{P}(3 \mathrm{HB}-c o-3 \mathrm{HP})$ : Fractions from sample $\mathrm{A}(\square)$ and $\mathrm{C}(\mathrm{O})$, original samples $\mathrm{A}-\mathrm{C}(\boldsymbol{\square})$, and homopolymer $\mathrm{P}(3 \mathrm{HB})(\bullet), \operatorname{PPL}(\bullet)$.

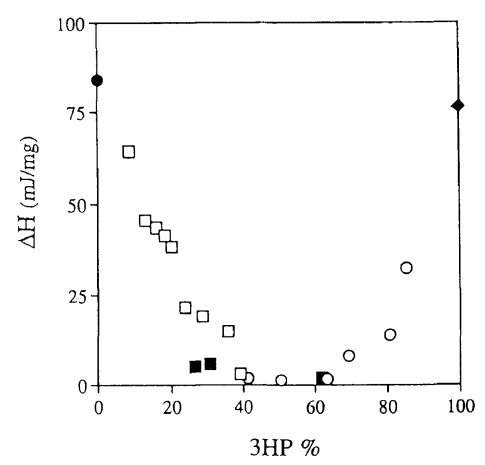

Figure 8. Heat of fusion $(\Delta H)$ vs. $3 \mathrm{HP}$ mol\% for the fractionated P(3HB-co-3HP): Fractions from sample A $(\square)$ and $C(O)$, original samples $\mathrm{A}-\mathrm{C}(\boldsymbol{\square})$, and homopolymer P(3HB) (๑), PPL $(\bullet)$.

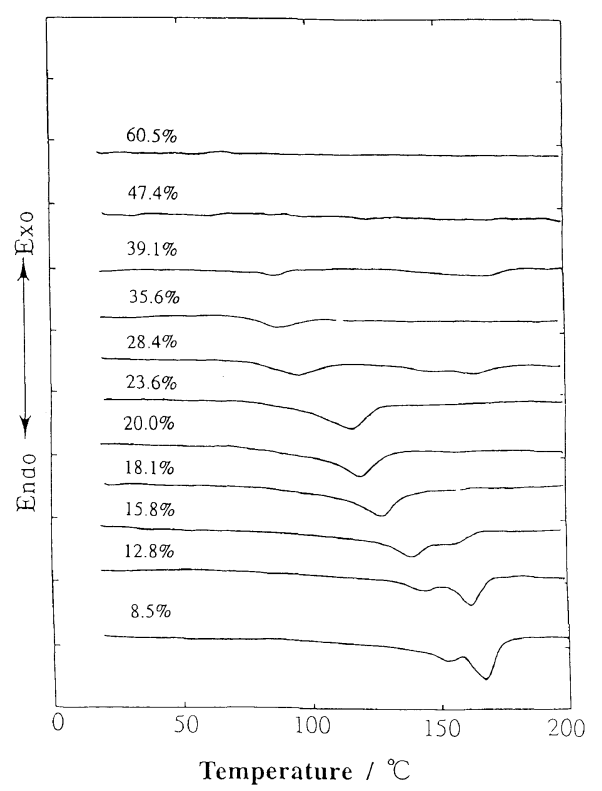

Figure 9. DSC diagram of a series of fractions of sample A prepared by cooling the melt and aged at $60^{\circ} \mathrm{C}$ for one month (first heating run).

mobilities of chains and segments enough to approach their equilibrium state even at ambient temperature.

The spherulite growth rates were measured for the samples before and after fractionation, which proved that spherulite radius increased linearly with growing time $(t)$ under different crystallization temperature $\left(T_{\mathrm{c}}\right)$, and the spherulite growth rate $(G)$ was taken as the slope of the $G(t) v s$. time $(t)$ plot. The result of spheru- 


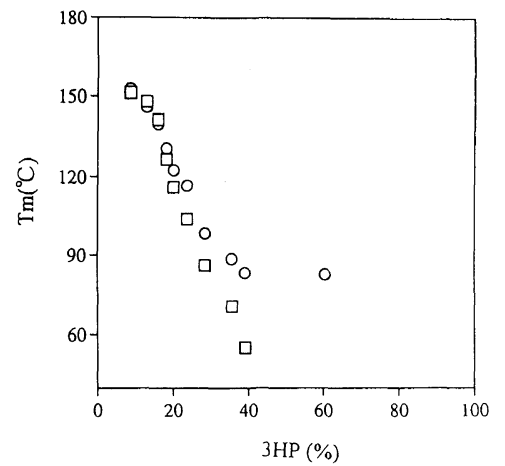

Figure 10. Melting points $\left(T_{\mathrm{m}}\right)$ vs. $3 \mathrm{HP} \mathrm{mol} \%$ for aged fractions of sample A as compared to that of cast film: $(\square)$ solution cast; $(O)$ cooled from the melt and aged.

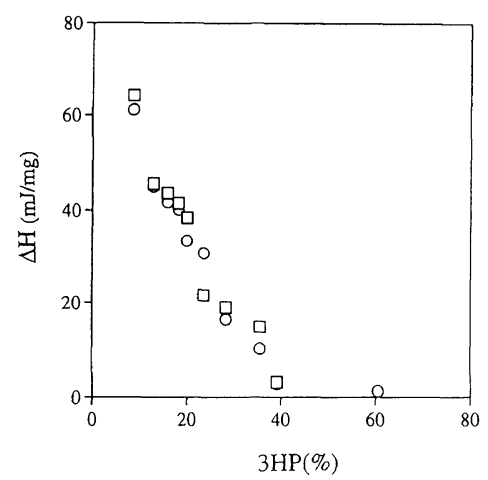

Figure 11. Heat of fusion $(\Delta H)$ vs. $3 \mathrm{HP}$ mol\% for aged fractions of sample A as compared to that of cast film: $(\square)$ solution cast; $(O)$ cooled from the melt and aged.

lite growth behavior was shown in Figure 12, which indicated that the temperature of maximum spherulite growth rate moved to lower temperature with the increase of 3HP unit content. Several sizes and profiles of spherulites were observed to be formed under different supercooling conditions. It was also found that the spherulite could not be detected through a microscope for $\mathrm{P}(3 \mathrm{HB}-c o-3 \mathrm{HP})$ with $3 \mathrm{HP}$ unit content more than $50 \mathrm{~mol} \%$. In these cases, perhaps only micro crystals existed, which made difficult the observation of spherulite growth. The capability of observing spherulite growth of the original samples with $3 \mathrm{HP}$ unit content more than $50 \mathrm{~mol} \%$ was due to the existence of the fractions with a lower 3HP unit constituent.

\section{CONCLUSION}

Three types of $\mathrm{P}(3 \mathrm{HB}-\mathrm{co}-3 \mathrm{HP})$ with different $3 \mathrm{HP}$ content were baterially synthesized by Alcaligens latus fed on mixed carbon sources of 3-hydroxypropionic acid, sucrose or 3-hydroxybutyric acid. Using a chloroform $/ n$ heptane mixed solvent, the as-produced $\mathrm{P}(3 \mathrm{HB}-\mathrm{co}-3 \mathrm{HP}) \mathrm{s}$ were found to be fractionated into a series of fractions with a narrow 3HP unit composition distibution. It was concluded that as-produced original copolyesters were natural mixtures or blends of $\mathrm{P}(3 \mathrm{HB}-c o-3 \mathrm{HP})$ with a broad 3HP unit composition distibution. Results of DSC measurements showed that one of as-produced $\mathrm{P}(3 \mathrm{HB}-$ $c o$-3HP) reveals only the feature of DSC melting behavior corresponding to that of minor $\mathrm{P}(3 \mathrm{HB}-c o-3 \mathrm{HP})$ fraction with 3HP composition remarkedly differed from the

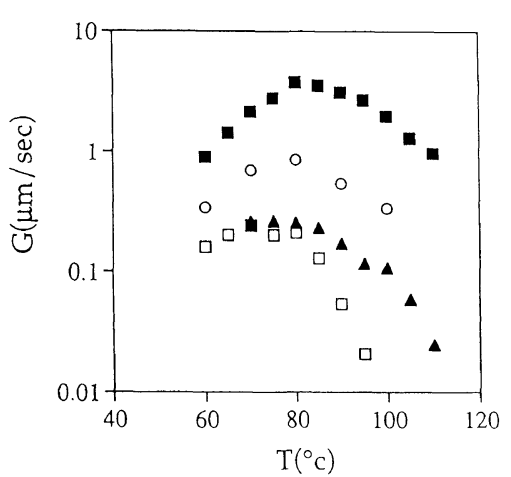

Figure 12. Spherulite growth rate $(G) v s$. crystalline temperature $\left(T_{\mathrm{c}}\right)$ : ( $\mathbf{E})$ homopolymer $\mathrm{P}(3 \mathrm{HB}) ;(\bigcirc)$ original sample $\mathrm{A} ;(\boldsymbol{\Delta})$ fraction of sample A (3HP unit content $18.1 \mathrm{~mol} \%$ ), ( $\square$ ) fraction of sample A (3HP unit content $15.8 \mathrm{~mol} \%$ ).

average $3 \mathrm{HP}$ content of as-produced original $\mathrm{P}(3 \mathrm{HB}-$ co$3 \mathrm{HP}$ ). The positions and intensities of DSC melting peaks varied with samples of different $3 \mathrm{HP}$ unit constituent, and trendency for melting peaks shifting to lower temperature with increasing $3 \mathrm{HP}$ content existed. It was also found that multiple melting peaks appeared, and the peaks at higher temperature were arisen from crystal reorganization in the case of lower heating rate, while the peaks at lower temperature were true melting temperature $\left(T_{\mathrm{m}}\right)$. A minimum $\Delta H$ was observed at a 3HP unit content of about $60 \mathrm{~mol} \%$, which is coincided with the study of crystallinity. ${ }^{20}$ Samples cooled from the melt showed DSC behavior almost similar to that of samples cast from solution, while melting point and $\Delta H$ were a little more increased in several samples of fractions due to thickening of lamella. It was found that maximum isothermal spherulite growth rate shifted to lower temperature with an increase of the 3HP composition, and several sizes of spherulites emerged under different supercooling situations. Spherulite growth rate could not be measured for fractions of more than $50 \mathrm{~mol} \% 3 \mathrm{HP}$ content, and only a large amount of micro crystals should be formed. The reason for capability to detect the spherulite growth of original polyesters was ascribed to the existence of fractions with lower 3HP unit composition.

Acknowledgments. This work was partly supported by a Grand-in-Aid for Developmental Scientific Research (1995, 1996) from the Ministry of Education, Science, and Culture of Japan.

\section{REFERENCES}

1. Y. Doi, “Microbial polyester," VCH Publishers, New York, 1990.

2. Y. Inoue and N. Yoshie, Prog. Polym. Sci., 17, 571 (1992).

3. R. Sharma and A. R. Ray, J. Macromol. Sci.-Rev., Macromol. Chem. Phys., C35(2), 327 (1995).

4. P. J. Hocking and R. H. Machessault, "Chemisty and Technology of Biodegradable Polymer," G. J. L. Griffin, Ed., Blakie, Academic \& Professional, London, New York, N.Y., 1994.

5. E. A. Dawes, "Novel Biodegradable Microbial Polymers," Kluwer Academic Publishers, Dordrecht, Boston, 1990.

6. H. Verhoogt, B. A Ramsay, and B. D. Favis, Polymer, 35, 515 (1994).

7. A. Koizumi, H. Abe, and Y. Doi, J. Macromol. Sci.-Pure Appl. Chem., A32(4), 759 (1995).

8. D. L. Vanderhart, W. J. Orts, and R. H. Marchessault, 
Macromolecules, 28, 6394 (1995).

9. P. J. Hocking and R. H. Marchessault, Macromolecules, 28, 6401 (1995).

10. R. H. Pearce and R. P. Marchessault, Macromolecules, 27, 3869 (1994).

11. R. Pearce, G. R. Brown, and R. H. Marchessault, Polymer, 35 , 3984 (1994).

12. R. Pearce, J. Jesudason, W. Orts, R. H. Marchessault, and S. Bloembergen, Polymer, 33, 4647 (1992).

13. N. Kamiya, M. Sakurai, Y. Inoue, and R. Chûjô, Macromolecules, 24, 3888 (1991).

14. R. Pearce and R. H. Marchessault, Polymer, 35, 3990 (1994).

15. G. J. M. de Koning, A. H. C. Scheeren, P. J. Lemstra, M. Peeters, and H. Reynaers, Polymer, 35, 4598 (1994).

16. S. Bloembergen, D. A. Holden, G. K. Hamer, T. L. Bluhm, and R. H. Marchessault, Macromolecules, 19, 2865 (1986).

17. K. Suehiro, Y. Chatani, and H. Tadokoro, Polym. J., 7, 352
(1975).

18. Y. Kumagai and Y. Doi, Polym. Degrad. Stab., 37, 253 (1992).

19. M. Hiramitsu and Y. Doi, Polymer, 34, 4782 (1993).

20. E. Shimamura, M. Scandola, and Y. Doi, Macromolecules, 27, 4429 (1994).

21. S. Nagamuna, M. Kunioka, and Y. Doi, Macromolecules Report, A28 (Suppl. 1), 15 (1991).

22. H. Mitomo, N. Morishita, and Y. Doi, Macromolecules, 26, 5809 (1993).

23. N. Yoshie, H. Menju, H. Sato, and Y. Inoue, Macromolecules, 28, 6516 (1995).

24. N. Yoshie, H. Menju, H. Sato, and Y. Inoue, Polym. J., 28, 45 (1996).

25. M. Ichikawa, K. Nakamura, N. Yoshie, N. Asakawa, Y. Inoue, and Y. Doi, Macromol. Chem. Phys., 97, 2467 (1996).

26. K. Nakamura, N. Yoshie, M. Sakurai, and Y. Inoue, Polymer, 35, 193 (1994). 